OPEN ACCESS

Edited by:

Tie Liu,

University of Florida, United States

Reviewed by:

Tao Feng,

Shanghai Institute of

Technology, China

Karin Albornoz,

University of Concepcion, Chile

*Correspondence:

Morteza Soleimani Aghdam soleimaniaghdam@eng.ikiu.ac.ir

Specialty section:

This article was submitted to Nutrition and Food Science Technology,

a section of the journal

Frontiers in Nutrition

Received: 22 September 2020 Accepted: 03 March 2021

Published: 01 April 2021

Citation:

Aghdam MS, Alikhani-Koupaei M and Khademian R (2021) Delaying Broccoli Floret Yellowing by Phytosulfokine a Application During Cold Storage.

Front. Nutr. 8:609217. doi: 10.3389/fnut.2021.609217

\section{Delaying Broccoli Floret Yellowing by Phytosulfokine $\alpha$ Application During Cold Storage}

\author{
Morteza Soleimani Aghdam ${ }^{1 *}$, Majid Alikhani-Koupaei $^{2}$ and Raheleh Khademian ${ }^{3}$ \\ ${ }^{1}$ Department of Horticultural Science, Imam Khomeini International University, Qazvin, Iran, ${ }^{2}$ Department of Production \\ Engineering and Plant Genetics, Faculty of Agriculture, Higher Education Complex of Saravan, Saravan, Iran, ${ }^{3}$ Department of \\ Genetic and Plant Breeding, Faculty of Agriculture and Natural Resources, Imam Khomeini International University, Qazvin, \\ Iran
}

During postharvest life, broccoli suffers from floret yellowing confining its economic and nutritional value. The objective of the present study was to explore the mechanisms employed by phytosulfokine $\alpha$ (PSK $\alpha$ ) at $150 \mathrm{nM}$ for delaying floret yellowing in broccoli during storage at $4^{\circ} \mathrm{C}$ for 28 days. Our results showed that the higher endogenous accumulation of hydrogen sulfide $\left(\mathrm{H}_{2} \mathrm{~S}\right)$ resulting from the higher gene expression and activities of I-cysteine desulfhydrase $(L C D)$ and d-cysteine desulfhydrase $(D C D)$ in broccoli floret treated with $150 \mathrm{nM}$ PSK $\alpha$ may serve as an endogenous signaling molecule for delaying senescence. Moreover, the suppressed ethylene biosynthesis in broccoli floret treated with $150 \mathrm{nM}$ PSKa might be ascribed to lower gene expression and activities of ACC synthase (ACS) and ACC oxidase (ACO). Furthermore, lower gene expression and activities of $\mathrm{Mg}^{2+}$ dechelatase $(M D C)$, pheophytinase $(P P H)$, and pheophorbide a oxygenase $(\mathrm{PaO})$ might be the reasons for the higher accumulation of chlorophyll in broccoli floret treated with $150 \mathrm{nM} \mathrm{PSK} \alpha$. Based on our findings, exogenous PSK $\alpha$ application could be employed as signaling bioactive hormone for retarding floret yellowing of broccoli during storage at $4^{\circ} \mathrm{C}$ for 28 days.

Keywords: chlorophyll degradation, ethylene biosynthesis, floret yellowing, hydrogen sulfide, pheophorbide a oxygenase, phytosulfokine $\alpha$

\section{INTRODUCTION}

Owing to higher health-promoting bioactive molecules accumulation, broccoli has gained worldwide attention as a global healthy food crop, which is beneficial for ensuring human health by reducing the risk of chronic diseases, such as cancer, cardiovascular diseases, and neurodegenerative diseases in industrial countries (1).

By harvesting broccoli prematurely, a high accumulation of intracellular reactive oxygen species (ROS) (2), an insufficient intracellular supply of $\operatorname{ATP}(3,4)$, an imbalance of intracellular hormones, signified by a higher biosynthesis of ethylene and a lower biosynthesis of cytokinin $(5,6)$, and chlorophyll degradation via the pheophorbide a oxygenase $(\mathrm{PaO})$ pathway $(2,6-9)$ may be the mechanisms for the accelerated broccoli senescence, manifested by floret yellowing, which confines its commercial value. In recent years, postharvest procedures, such as 1-methylcyclopropene (1MCP) (10), nitric oxide (2), brassinolide (6), putrescine (8), hydrogen sulfide $\left(\mathrm{H}_{2} \mathrm{~S}\right)(4,11)$, cytokinins (12), folic acid (13), melatonin (14), arginine, cysteine, and methionine (15), and 
phytosulfokine $\alpha$ (PSK $\alpha)$ (16-18), have been employed by researchers for delaying broccoli senescence manifested by floret yellowing during cold storage.

In plants, providing sufficient cysteine is crucial for $\mathrm{H}_{2} \mathrm{~S}$ biosynthesis by L-cysteine desulfhydrase (LCD) enzyme activity in the cytosol and mitochondria and D-cysteine desulfhydrase (DCD) enzyme activity in the mitochondria (19-21). By exogenous $\mathrm{H}_{2} \mathrm{~S}$ application, endogenous $\mathrm{H}_{2} \mathrm{~S}$ accumulation resulting from higher $L C D$ and $D C D$ gene expressions and enzyme activities has been beneficial for improving the marketability in horticultural crops by sufficient intracellular ATP supply by promoting $\mathrm{H}^{+}$-ATPase, $\mathrm{Ca}^{2+}$-ATPase, cytochrome c oxidase (CCO), and succinate dehydrogenase (SDH) enzyme activities, preventing chlorophyll degradation by suppressing chlorophyll b reductase $(C B R)$, chlorophyllase (Chlase), $\mathrm{Mg}^{2+}$ dechelatase $(M D C)$, pheophytinase $(P P H)$, and $\mathrm{PaO}$ gene expressions and enzyme activities, promoting endogenous proline accumulation by triggering pyrroline-5carboxylate synthase (P5CS) and ornithine aminotransferase $(O A T)$ gene expressions and enzyme activities along with hindering proline dehydrogenase $(P D H)$ gene expression and enzyme activity, promoting ROS scavenging superoxide dismutase $(S O D)$, catalase $(C A T)$, ascorbate peroxidase $(A P X)$, and glutathione reductase $(G R)$ gene expressions and enzyme activities leading to lower $\mathrm{O}_{2}^{-}$and $\mathrm{H}_{2} \mathrm{O}_{2}$ accumulation, keeping membrane integrity by presenting lower electrolyte leakage and malondialdehyde (MDA) accumulation resulting from lower phospholipase D (PLD) and lipoxygenase (LOX) enzyme activities, preventing ethylene biosynthesis by suppressing ACC synthase (ACS) and ACC oxidase (ACO) gene expressions and enzyme activities, promoting phenylpropanoid pathway activity by presenting higher phenylalanine ammonia lyase (PAL)/polyphenol oxidase (PPO) enzyme activity leading to higher phenols, flavonoids, and anthocyanins accumulation, promoting oxidative pentose phosphate pathway activity by presenting higher glucose 6-phosphate dehydrogenase (G6PDH) and 6-phosphogluconate dehydrogenase (6PGDH) enzyme activities for supplying NADPH and erythritol 4-phosphate, and promoting chitinase and $\beta$-1,3-glucanase gene expressions and enzyme activities $(4,22-30)$.

$\mathrm{PSK} \alpha \quad\left[\mathrm{Tyr}\left(\mathrm{SO}_{3} \mathrm{H}\right)-\mathrm{Ile}-\mathrm{Tyr}\left(\mathrm{SO}_{3} \mathrm{H}\right)-\mathrm{Thr}-\mathrm{Gln}\right]$ is a bioactive signaling tyrosine-disulfate pentapeptide hormone biosynthesized from a prepropeptide of 80-120 amino acid prepropeptides encoded by the PSKs gene $(31,32)$. By promoting cytosolic second messenger guanosine $3^{\prime}, 5^{\prime}$ cyclic monophosphate (cGMP) accumulation by employing exogenous PSK $\alpha$ application resulting from phytosulfokine receptor 1 (PAR1) kinase encapsulating guanylate cyclase activity, triggering cytosolic $\mathrm{Ca}^{2+}$ accumulation may be responsible for triggering friendly extracellular ATP and intracellular SnRK1 signaling pathways, triggering SUMO E3 ligase SIZ1 system activity accompanied by suppressing $\mathrm{NAD}^{+}$dissipating poly(ADP-ribose) polymerase 1 (PARP1) system activity for ensuring sufficient intracellular ATP supply resulting from higher $\mathrm{H}^{+}$-ATPase, $\mathrm{Ca}^{2+}$-ATPase, CCO, and $\mathrm{SDH}$ enzyme activities accompanied by sufficient intracellular NADPH supply resulting from higher G6PDH, 6PGDH, and methylenetetrahydrofolate dehydrogenase (MTHFD) enzyme activities, triggering ROS avoiding alternative oxidase $(A O X)$ and uncoupling protein (UCP1) gene expressions and scavenging $S O D, C A T, A P X$, and $G R$ gene expressions and enzyme activities, promoting phenylpropanoid pathway activity by presenting higher $P A L$ and chalcone synthase (CHS) gene expressions and enzyme activities leading to higher phenols, flavonoids, and anthocyanins accumulation, promoting ascorbic acid accumulation resulting from higher l-galactono-1,4-lactone dehydrogenase $(G L D H)$ gene expression along with lower ascorbic acid oxidase $(A A O)$ gene expression, promoting endogenous melatonin accumulation resulting from higher tryptophan decarboxylase (TDC), tryptamine 5-hydroxylase $(T 5 H)$, serotonin $\mathrm{N}$-acetyltransferase (SNAT), and $\mathrm{N}$-acetylserotonin $\mathrm{O}$-methyltransferase (ASMT) gene expressions, promoting endogenous cytokinin accumulation resulting from higher isopentenyl transferase (IPT) gene expression concomitant with lower cytokinin oxidase $(C K O)$ gene expression, suppressing $P L D$ and $L O X$ gene expressions and enzyme activities, triggering heat shock protein (HSP70 and HSP90) gene expressions, and improving 2,2-diphenyl1-picrylhydrazyl (DPPH), ferric ion reducing antioxidant power (FRAP), and DPPH scavenging capacity resulting from higher phenols, flavonoids, anthocyanins, and ascorbic acid accumulation may be responsible for attenuating chilling injury and fungal decay, delaying senescence and maintaining the nutritional quality of fruits and vegetables during cold storage (16-18, 33-37). However, there are ongoing attempts to introduce safe and operative procedures for avoiding floret yellowing and preserving the floret quality of broccoli during cold storage.

Therefore, triggering endogenous PSK $\alpha$ signaling pathway by exogenous PSK $\alpha$ application or endogenous PSK $\alpha$ accumulation may be efficient for relieving chilling injury and fungal decay, delaying senescence and keeping the quality of horticultural crops during postharvest life (16-18, 33-37). The present study aimed to investigate the connection between exogenous PSK $\alpha$ application and broccoli floret yellowing and elucidate its mechanisms from the perspective of endogenous $\mathrm{H}_{2} \mathrm{~S}$ accumulation by $L C D$ and $D C D$ gene expressions and enzyme activities, chlorophyll degradation by $M D C, P P H$, and $P a O$ gene expressions, and enzyme activities accompanied by ethylene biosynthesis by ACS and ACO gene expressions and enzyme activities by employing exogenous PSK $\alpha$ application at 0 and $150 \mathrm{nM}$ during storage at $4^{\circ} \mathrm{C}$ for 28 days.

\section{MATERIALS AND METHODS Broccoli and PSK $\alpha$ Application}

Broccoli (Brassica oleracea var. italica) was harvested at commercial maturity when the individual floret was still closed and was dark green and the inflorescence was compact. Healthy broccoli heads with uniform size, color, and maturity stage were selected for PSK $\alpha$ treatment. PSK $\alpha$ (soluble in sterile water, 1 $\mathrm{mg} / \mathrm{ml}$ ) was provided by Pepmic Co., Ltd., Suzhou, China. For PSK $\alpha$ treatment, 240 broccoli heads were allocated into two groups of 120 (40 heads per replicate) for the experimental 
treatments, applied by spraying the heads with $25 \mathrm{ml}$ of PSK $\alpha$ at 0 (control; double distilled water, $\mathrm{ddH}_{2} \mathrm{O}$ ) or $150 \mathrm{nM}$ according to Aghdam et al. (16) and Aghdam and Luo (18). After drying overnight, the broccoli heads were packaged in polyethylene bags $(50 \times 80 \mathrm{~cm}, 0.04 \mathrm{~mm})$ and stored at $4 \pm 0.5^{\circ} \mathrm{C}$ and $85 \%$ relative humidity for 28 days. Then, every 7 days during storage at $4^{\circ} \mathrm{C}$, floret from 10 broccolis was excised, immediately frozen in liquid nitrogen, powdered, and stored at $-80^{\circ} \mathrm{C}$ for biochemical and gene expression analysis. For biochemical and gene expression analysis, three technical replications were carried out by three extractions from each biological replication to avoid instrumental error. The means of three technical replications are considered as one biological replication.

\section{Broccoli Floret Yellowing}

Broccoli floret yellowing (\%) was assessed by a scale from 0 to 9 as stated by Shi et al. (2), where 0 indicates all dark green, 1 indicates $25 \%$ yellowing, 5 indicates $50 \%$ yellowing, 7 indicates $75 \%$ yellowing, and 9 indicates $100 \%$ yellowing of the broccoli floret.

\section{Chlorophyll Degradation by MDC and PPH Enzyme Activities}

Chlorophyll accumulation in broccoli floret was measured according to Gómez-Lobato et al. (38), by homogenizing $1 \mathrm{~g}$ of frozen powder with $10 \mathrm{ml}$ of $80 \%(\mathrm{v} / \mathrm{v})$ acetone and centrifugation at $10,000 \times g$ for $10 \mathrm{~min}$ at $4^{\circ} \mathrm{C}$. By measuring absorbance at 663 and $645 \mathrm{~nm}$, chlorophyll accumulation was calculated using the formula:

Chlorophyll accumulation $\left(\mathrm{g} \mathrm{kg}^{-1} \mathrm{FW}\right)=\left(17.76 \times \mathrm{A}_{645 \mathrm{~nm}}\right)$ $+\left(7.34 \times \mathrm{A}_{663 \mathrm{~nm}}\right)$.

For analyzing MDC and PPH enzyme activities, $1 \mathrm{~g}$ of frozen powder was homogenized with $10 \mathrm{ml}$ of cold acetone. After centrifugation at $12,000 \times g$ for $5 \mathrm{~min}$ at $4{ }^{\circ} \mathrm{C}$, the precipitate was used for assaying $\mathrm{MDC}$ and $\mathrm{PPH}$ enzyme activities according to 38. MDC enzyme activity was assayed by pheophorbide a formation at $686 \mathrm{~nm}$ and was expressed in mkatals produced per mass of protein, mkat $\mathrm{kg}^{-1}$. PPH enzyme activity was assayed by pheophorbide a formation at $667 \mathrm{~nm}$ and was expressed in mkatals produced per mass of protein, $\mathrm{mkat} \mathrm{kg}^{-1}$.

\section{Ethylene Biosynthesis by ACS and ACO Enzyme Activities}

Ethylene production was measured using gas chromatography as stated by Fan et al. (39). Ethylene production was expressed as $\mu \mathrm{g}$ $\mathrm{kg}^{-1} \mathrm{~h}^{-1}$ on a fresh weight basis. For ACS enzyme activity, $1 \mathrm{~g}$ of frozen powder was homogenized with $5 \mathrm{ml}$ of $100 \mathrm{mM}$ sodium phosphate buffer ( $\mathrm{pH}$ 9.0) containing $5 \mu \mathrm{M}$ pyridoxal phosphate, $4 \mathrm{mM} \beta$-mercaptoethanol, $1 \mathrm{mM}$ ethylenediaminetetraacetic acid (EDTA), and 10\% (v/v) glycerol. After centrifugation at $16,000 \times g$ for $20 \mathrm{~min}$ at $4^{\circ} \mathrm{C}$, the supernatant was used for ACS enzyme activity assaying according to Suzuki et al. (40). ACS activity was expressed based on ACC production as $\mu \mathrm{mol} \mathrm{kg} \mathrm{kg}^{-1}$ on a fresh weight basis. For ACO enzyme activity, $1 \mathrm{~g}$ of frozen powder was homogenized with $10 \mathrm{ml}$ of $100 \mathrm{mM}$ Tris- $\mathrm{HCl}$ buffer $(\mathrm{pH}$ 7.2 ) containing $30 \%(\mathrm{w} / \mathrm{v})$ glycerol, $10 \mathrm{mM}$ sodium ascorbate, and $5 \mathrm{mM}$ dithiothreitol (DTT). After centrifugation at $14,000 \times g$ for $20 \mathrm{~min}$ at $4{ }^{\circ} \mathrm{C}$, the supernatant was used for ACO enzyme activity assaying according to Suzuki et al. (41). ACO activity was expressed based on ethylene production as $\mu \mathrm{mol} \mathrm{kg}{ }^{-1} \mathrm{~h}^{-1}$ on a fresh weight basis.

\section{Endogenous $\mathrm{H}_{2} \mathrm{~S}$ Accumulation by LCD and DCD Enzyme Activities}

For endogenous $\mathrm{H}_{2} \mathrm{~S}$ accumulation assaying by methylene blue method as stated by $\mathrm{Li}$ et al. (4), $1 \mathrm{~g}$ of frozen powder was homogenized with $10 \mathrm{ml}$ of $50 \mathrm{mM}$ phosphate buffer saline ( $\mathrm{pH}$ 6.8) containing $0.2 \mathrm{M}$ ascorbic acid and $0.1 \mathrm{M}$ EDTA. After centrifugation at $10,000 \times g$ for $20 \mathrm{~min}$, the supernatants were mixed in a test tube containing $0.1 \mathrm{M}$ phosphate buffer saline (pH 7.4), $2 \mathrm{mM}$ phosphopyridoxal, and $10 \mathrm{mM}$ L-cysteine. The released $\mathrm{H}_{2} \mathrm{~S}$ was absorbed in a zinc acetate trap. The absorbance was measured at $667 \mathrm{~nm}$, and the calibration curve was established with $\mathrm{Na}_{2} \mathrm{~S}$ solution concentrations. Endogenous

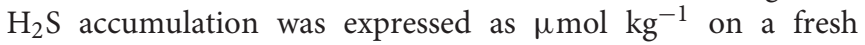
weight basis. The LCD and DCD enzyme activities were analyzed as stated by $\mathrm{Li}$ et al. (4). Then, $1 \mathrm{~g}$ of frozen powder was homogenized with $20 \mathrm{mM}$ Tris- $\mathrm{HCl}(\mathrm{pH} 8.0)$. The homogenate was centrifuged at $12,000 \times g$ for $20 \mathrm{~min}$. For LCD and DCD enzyme activity assays, $1 \mathrm{ml}$ of supernatant was mixed with $1 \mathrm{ml}$ of mixture solution containing $100 \mathrm{mM}$ Tris- $\mathrm{HCl}$ ( $\mathrm{pH} 9.0$ for LCD enzyme and 8.0 for DCD enzyme), $0.8 \mathrm{mM}$ L-cysteine for LCD enzyme and D-cysteine for DCD enzyme, and $2.5 \mathrm{mM}$ DTT. After incubation at $37^{\circ} \mathrm{C}$ for $15 \mathrm{~min}$, the reaction was terminated by adding $100 \mu \mathrm{l}$ of $30 \mathrm{mM} \mathrm{FeCl}_{3}$ dissolved in $1.2 \mathrm{M}$ $\mathrm{HCl}$ and $100 \mu \mathrm{l}$ of $20 \mathrm{mM}$ N,N-dimethyl-p-phenylenediamine (DMPD) dissolved in $7.2 \mathrm{M} \mathrm{HCl}$. Then, the formation of methylene blue was recorded at $670 \mathrm{~nm}$. A calibration curve was established with $\mathrm{Na}_{2} \mathrm{~S}$ solution concentrations. The LCD and DCD enzyme activities were expressed on a fresh weight basis as $\mu \mathrm{mol} \mathrm{kg}{ }^{-1} \mathrm{~h}^{-1}$.

\section{Genes Expression Assay by RT-qPCR}

A $1 \mathrm{~g}$ of frozen powder was used for total RNA extraction from broccoli floret by Trizol reagent (Invitrogen, CA, USA). To confirm total RNA quantity and quality, we determined the absorbance at $260 \mathrm{~nm}$ by using a Thermo Scientific ${ }^{\mathrm{TM}}$ NanoDrop ${ }^{\mathrm{TM}}$ One Spectrophotometer and 1.0\% agarose gel electrophoresis. The cDNA was synthesized from $2 \mu \mathrm{g}$ of total RNA using the SuperScript ${ }^{\circledR}$ RT (Invitrogen, CA, USA) kit according to the manufacturer's instructions. The cDNA was used as a template for assaying the relative expression of genes by quantitative reverse transcription-PCR (RT-qPCR) utilizing a StepOne ${ }^{\mathrm{TM}}$ Real-Time PCR System. The final volume of $10 \mu \mathrm{l}$ containing $1 \mu \mathrm{l}$ of $\mathrm{cDNA}, 100 \mathrm{nM}$ primers (Supplementary Table 1), and $5 \mu$ l of $2 \times$ SYBR GREEN I Master Mix (TaKaRa, Japan) was prepared according to the instruction provided by the manufacturer. All primers' specificity was determined using the BLAST sequence alignment with PrimerBLAST software. To better quantify the relative expression of the genes, the threshold cycle $(\mathrm{Ct})$ value was normalized to the Actin Ct value and calculated following $2^{-\Delta \Delta C t}$ according to Livak and Schmittgen (42). 


\section{Statistical Analysis}

The experiment was planned using split plots in a time model based on a completely randomized design (CRD). For biochemical and genes expression analysis, three technical replications were carried out by three extractions from each biological replication to avoid instrumental error. The means of three technical replications are considered as one biological replication. All data were expressed as mean \pm standard error (SE) from three biological replications. ANOVA was carried out, and the mean was compared using Tukey's test at a significance level of 0.01 using the SPSS software (version 19.0).

\section{RESULTS AND DISCUSSION}

\section{Broccoli Floret Yellowing and Ethylene Production}

As depicted in Supplementary Figure 1, broccoli treated with PSK $\alpha$ at $150 \mathrm{nM}$ exhibited the lowest floret yellowing during storage at $4^{\circ} \mathrm{C}$ for 28 days $(P<0.01)$. Additionally, retarding floret yellowing in broccoli treated with PSK $\alpha$ at $150 \mathrm{nM}$ was concomitant with lower ethylene production $(P<0.01$; Figure 1), which might be attributed to lower ACS1 and ACO1 gene expressions and enzyme activities $(P<0.01$; Figure 1) during storage at $4^{\circ} \mathrm{C}$ for 28 days. During postharvest life, higher ethylene biosynthesis by ACS and ACO gene expressions and enzyme activities may be the reason for triggering floret yellowing in broccoli by promoting membrane phospholipids degradation by $P L D$ gene expression and enzyme activity leading to free fatty acids supplying for peroxidation by $L O X$ gene expression and enzyme activity. Higher LOX activity not only is liable for deteriorating membrane fluidity and integrity signifying higher MDA accumulation but also is liable for endogenous jasmonic acid accumulation for accelerating broccoli floret yellowing by motivating $\mathrm{CBR}, \mathrm{PPH}$, and $\mathrm{PaO}$ gene expressions and enzyme activities $(38,43,44)$. Hence, suppressing ethylene biosynthesis accompanied by hampering membrane deteriorating LOX enzymes activity by exogenous 1-MCP and exogenous cytokinin application or IPT gene overexpression has been employed successfully for suppressing floret yellowing in broccoli during postharvest life $(5,40,45,46)$. According to our results, lower ethylene production in broccoli floret treated with PSK $\alpha$ at $150 \mathrm{nM}$ might be attributed to lower ACS1 and ACO1 gene expressions and enzyme activities during storage at $4^{\circ} \mathrm{C}$ for 28 days. Hence, low temperature storage $\left(4^{\circ} \mathrm{C}\right)$ synergistically by exogenous PSK $\alpha$ application may be crucial for suppressing ethylene production efficient for suppressing floret senescence manifested by yellowing.

\section{Broccoli Floret Chlorophyll Degradation}

As depicted in Figure 2, broccoli treated with PSK $\alpha$ at $150 \mathrm{nM}$ exhibited higher chlorophyll accumulation $(\mathrm{P}<0.01$; Figure 2$)$, which might be attributed to lower $\mathrm{PPH}$ and $\mathrm{PaO}$ gene expressions $(P<0.01$; Figure 2$)$ accompanied by lower MDC and $\mathrm{PPH}$ enzyme activities $(P<0.01$; Figure 2$)$ during storage at $4{ }^{\circ} \mathrm{C}$ for 28 days. During postharvest senescence, $\mathrm{PaO}$ pathway activity is liable for chlorophyll degradation. During PAO pathway activity, Chlase enzyme activity is liable for phytol removal from chlorophyll a leading to chlorophyllide a producing in the thylakoid membrane. Chen et al. (47) reported that the silencing Chlase gene expression suppressed floret yellowing during postharvest life. After chlorophyll a dephytylation by Chlase, MDC enzyme activity is liable for $\mathrm{Mg}^{2+}$ removing from chlorophyllide a producing pheophorbide a in chloroplast stroma (48). In broccoli floret during senescence, demetallation may be the reason for producing pheophytin a from chlorophyll a by MDC enzyme activity. Then, $\mathrm{PPH}$ enzyme activity is liable for producing pheophorbide a in chloroplast stroma from pheophytin a (49-51). Suppressing floret yellowing in broccoli by cytokinin treatment might be ascribed to repressing $\mathrm{PPH}$ gene expression, and accelerating floret yellowing in broccoli by ethylene treatment might be ascribed to enhancing $\mathrm{PPH}$ gene expression (50). Then, $\mathrm{PaO}$ enzyme activity is liable for producing red chlorophyll catabolite (RCC) from pheophorbide a by oxidative chlorine ring-opening (48). Cai et al. (6) reported that suppressing floret yellowing in broccoli by exogenous brassinolide application might be ascribed to lower ethylene biosynthesis resulting from lower ACS and ACO gene expressions accompanied by higher chlorophyll accumulation resulting from lower Chlase, $\mathrm{PPH}$, and $\mathrm{PaO}$ gene expressions. Hence, higher chlorophyll accumulation in broccoli floret treated with PSK $\alpha$ at $150 \mathrm{nM}$ might be attributed to lower $\mathrm{PPH}$ and $\mathrm{PaO}$ gene expressions accompanied by lower MDC and $\mathrm{PPH}$ enzyme activities during storage at $4^{\circ} \mathrm{C}$ for 28 days.

\section{Broccoli Floret Endogenous $\mathrm{H}_{2} \mathrm{~S}$ Accumulation}

As depicted in Figure 3, broccoli treated with PSK $\alpha$ at $150 \mathrm{nM}$ exhibited higher endogenous $\mathrm{H}_{2} \mathrm{~S}$ accumulation $(P<0.01$; Figure 3), which might be attributed to higher $L C D$ and $D C D$ gene expressions and enzyme activities $(P<0.01$; Figure 3$)$ during storage at $4{ }^{\circ} \mathrm{C}$ for 28 days. $\mathrm{Hu}$ et al. (22) reported that suppressing leaf yellowing in spinach treated with $\mathrm{H}_{2} \mathrm{~S}$ might be ascribed to endogenous $\mathrm{H}_{2} \mathrm{~S}$ accumulation resulting from higher LCD and DCD enzyme activities efficient for sufficient intracellular ATP supply resulting from electron transferring from sulfide to CCO for accelerating electron transport system activity accompanied by higher chlorophyll accumulation resulting from lower Chlase and MDC enzyme activities along with higher SOD and CAT enzyme activities leading to higher $\mathrm{DPPH}$ and $\mathrm{O}_{2}^{-}$scavenging capacity, keeping membrane integrity signifying lower electrolyte leakage and MDA accumulation. Li et al. (4) reported that suppressing floret yellowing in broccoli treated with $\mathrm{H}_{2} \mathrm{~S}$ might be ascribed to endogenous $\mathrm{H}_{2} \mathrm{~S}$ accumulation resulting from higher LCD and DCD enzyme activities efficient for sufficient intracellular ATP supply resulting from higher $\mathrm{H}^{+}$-ATPase, $\mathrm{Ca}^{2+}$-ATPase, $\mathrm{SDH}$, and $\mathrm{CCO}$ enzyme activities accompanied by sufficient intracellular NADPH supply resulting from higher G6PDH and 6PGDH enzyme activities. Liu et al. (26) reported that suppressing daylily flower senescence treated with $\mathrm{H}_{2} \mathrm{~S}$ might be ascribed to endogenous $\mathrm{H}_{2} \mathrm{~S}$ accumulation resulting from higher LCD and DCD enzyme activities efficient for sufficient intracellular ATP supply resulting from higher $\mathrm{H}^{+}$-ATPase, $\mathrm{Ca}^{2+}$-ATPase, 

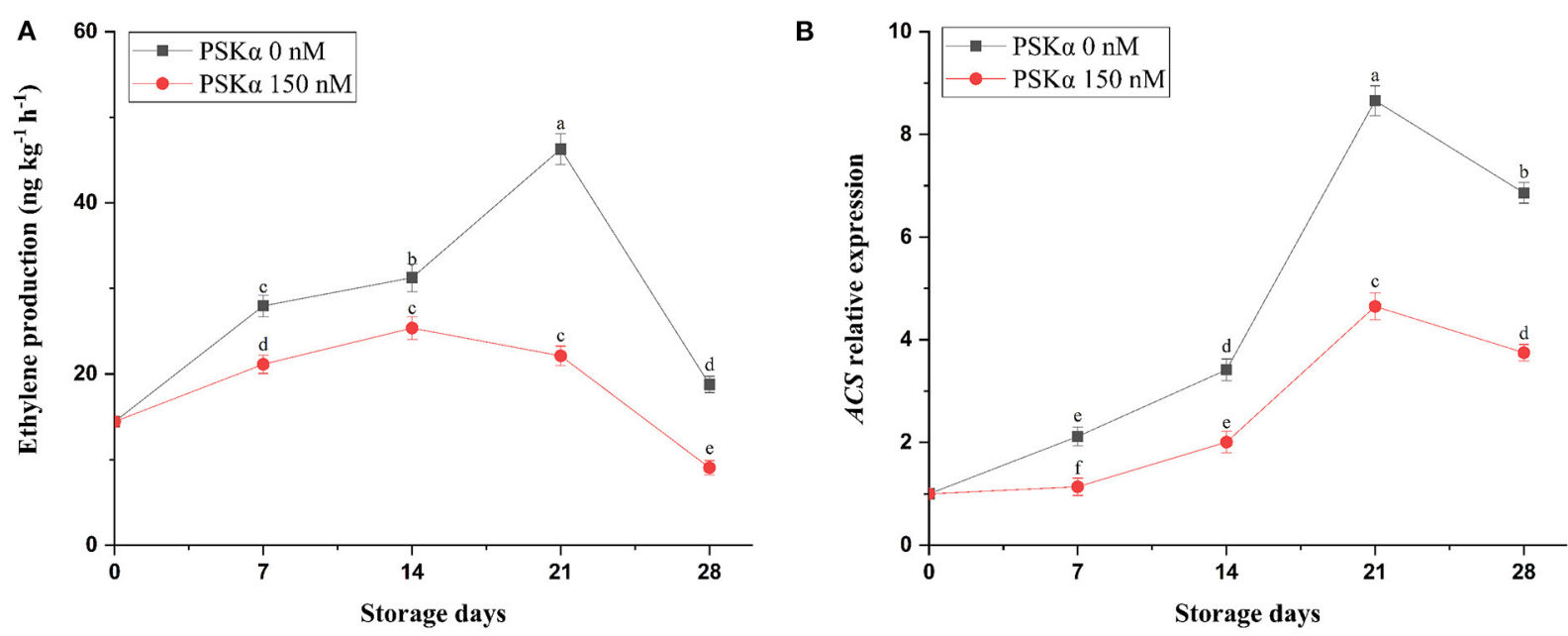

C

D
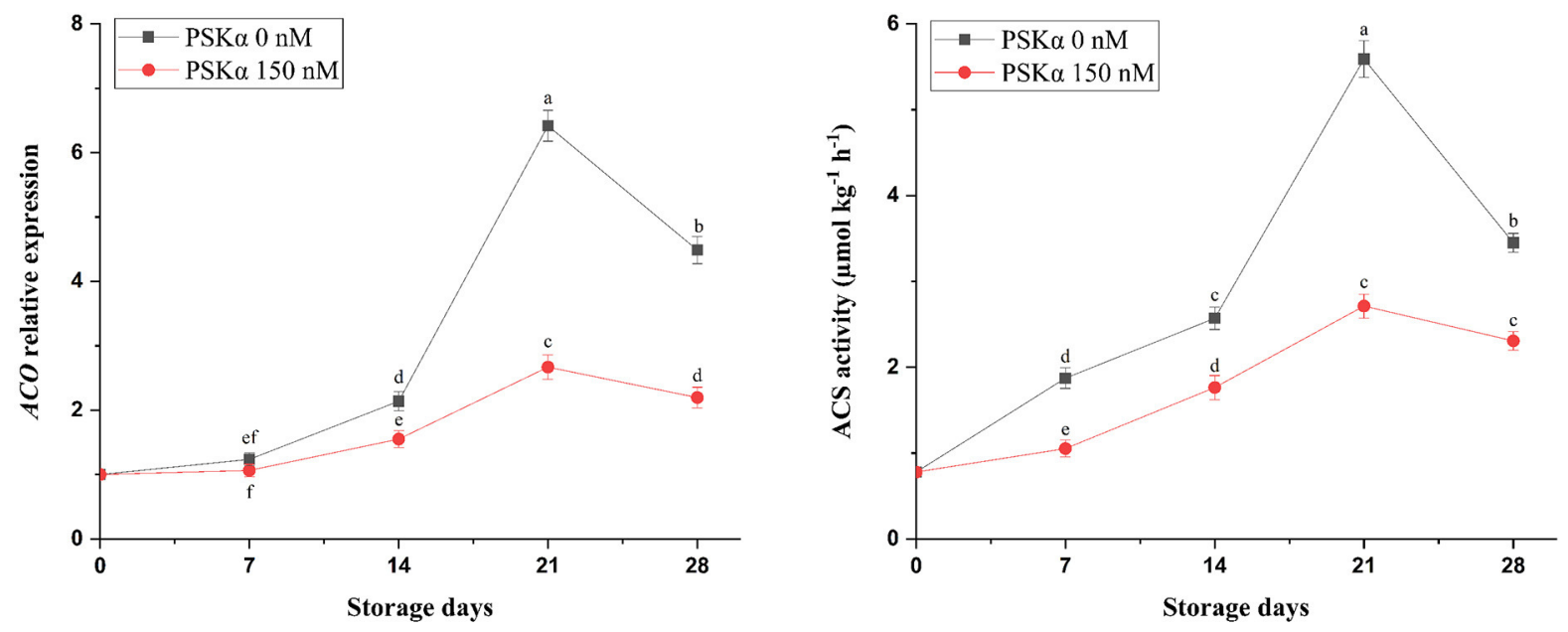

E

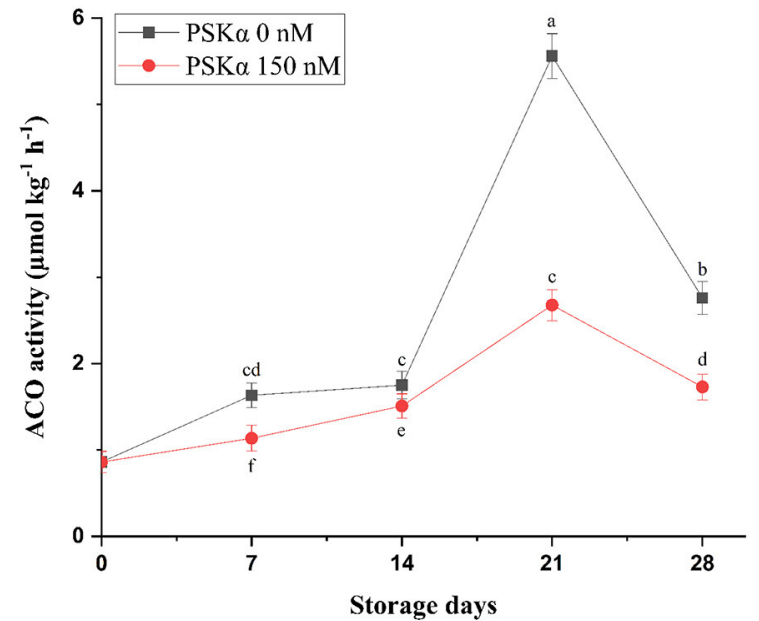

FIGURE 1 | Ethylene production (A) accompanied by ACS and ACO gene expressions (B,C) and enzyme activities (D,E) in broccoli floret treated with PSK $\alpha$ at 0 and $150 \mathrm{nM}$ during storage at $4^{\circ} \mathrm{C}$ for 28 days. Data shown are mean values of $n=3$, and the error bars represent standard errors of the means. Tukey's test at $P=$ 0.05 level. 

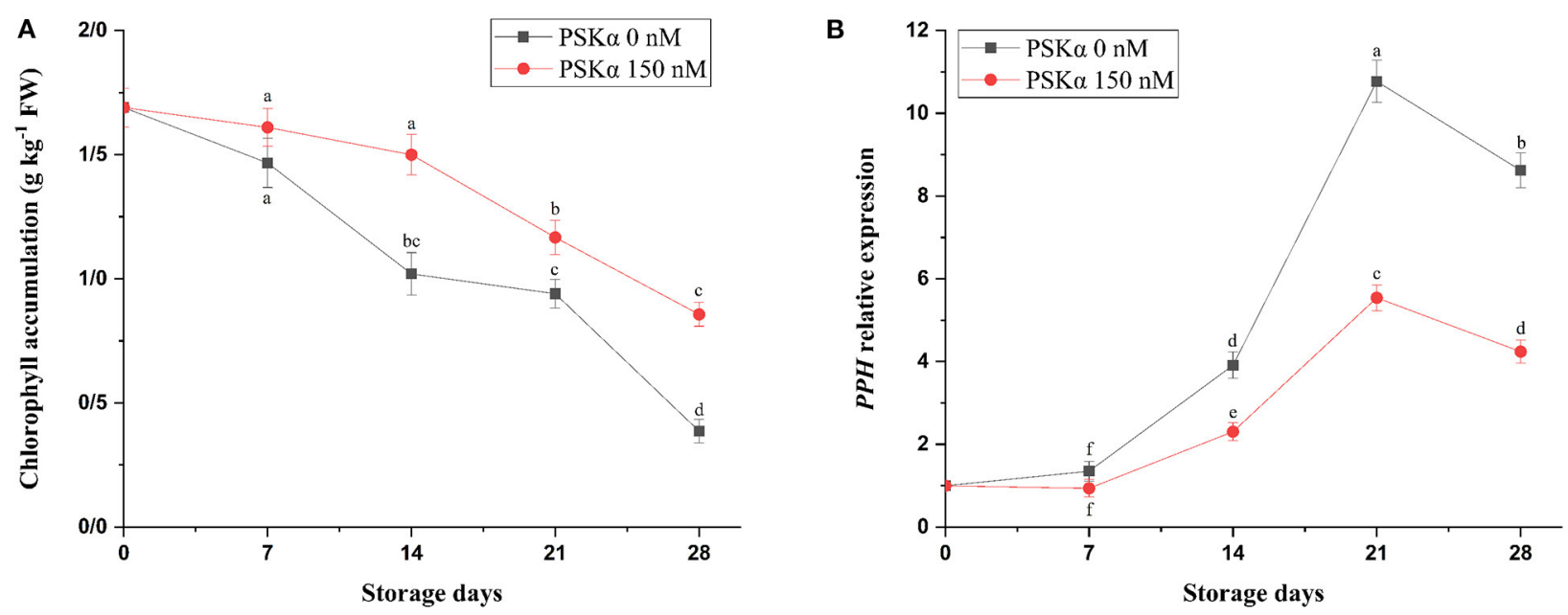

C

D
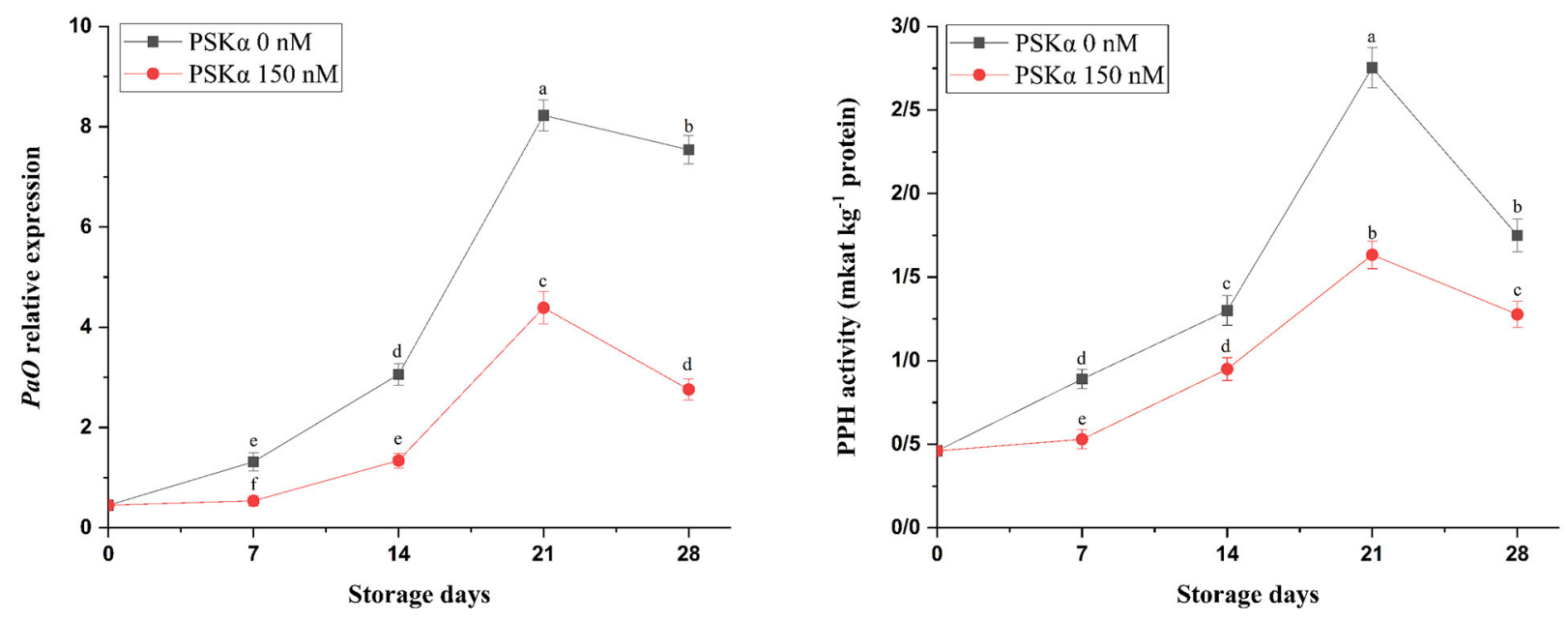

E

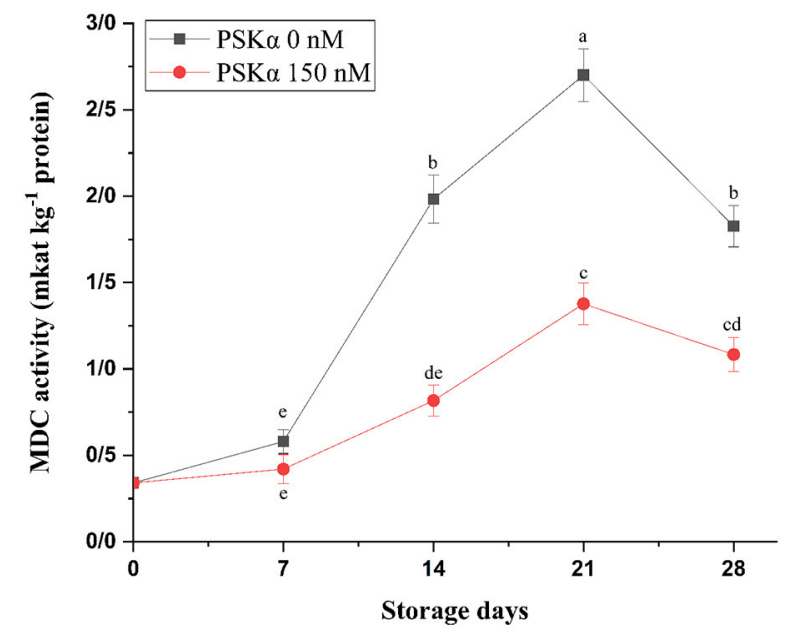

FIGURE 2 | Chlorophyll accumulation (A) accompanied by PPH and PAO gene expressions (B,C) and MDC and PPH enzyme activities (D,E) in broccoli floret treated with PSKa at 0 and $150 \mathrm{nM}$ during storage at $4^{\circ} \mathrm{C}$ for 28 days. Data shown are mean values of $n=3$, and the error bars represent standard errors of the means. Tukey's test at $P=0.05$ level. 


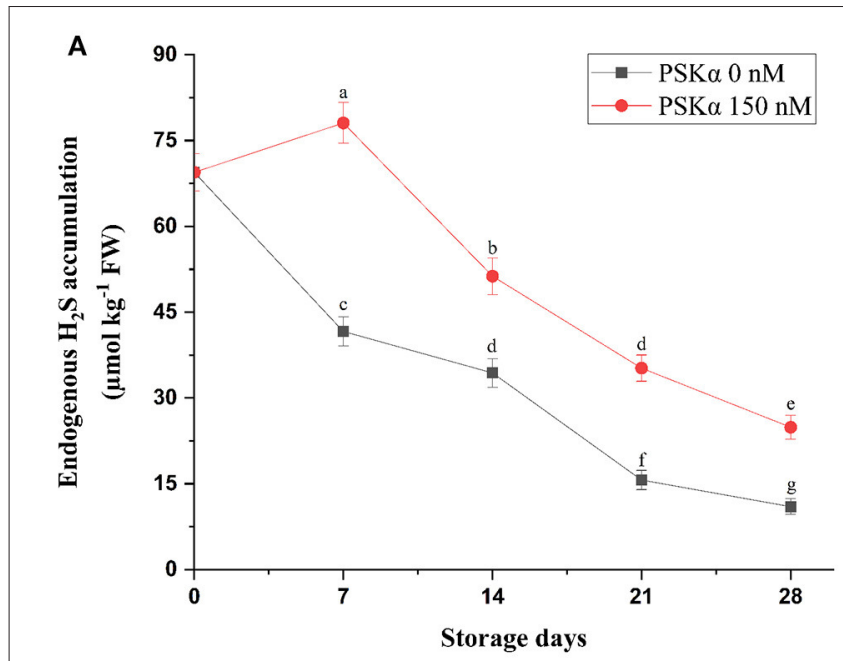

B

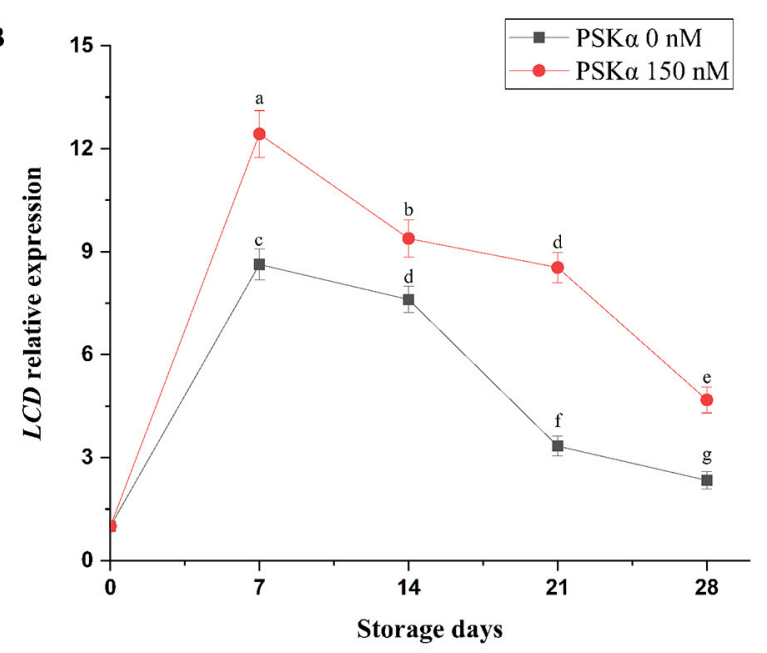

C

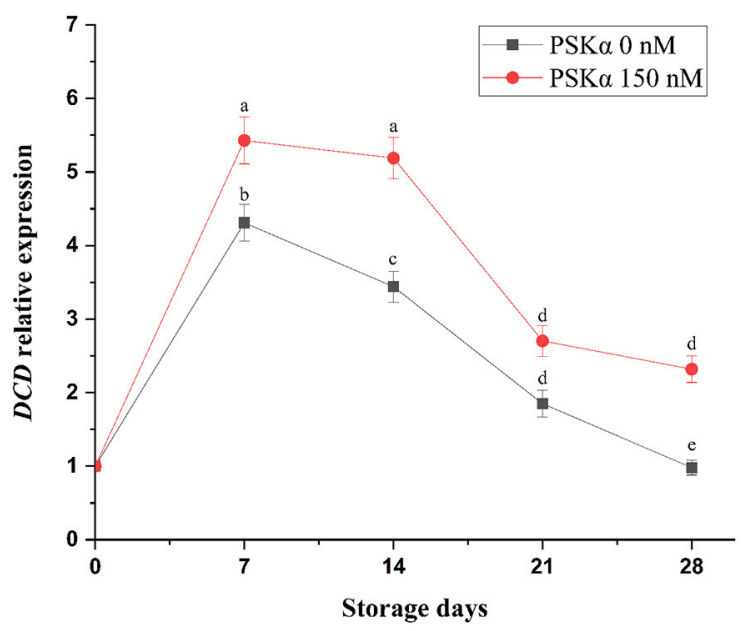

D

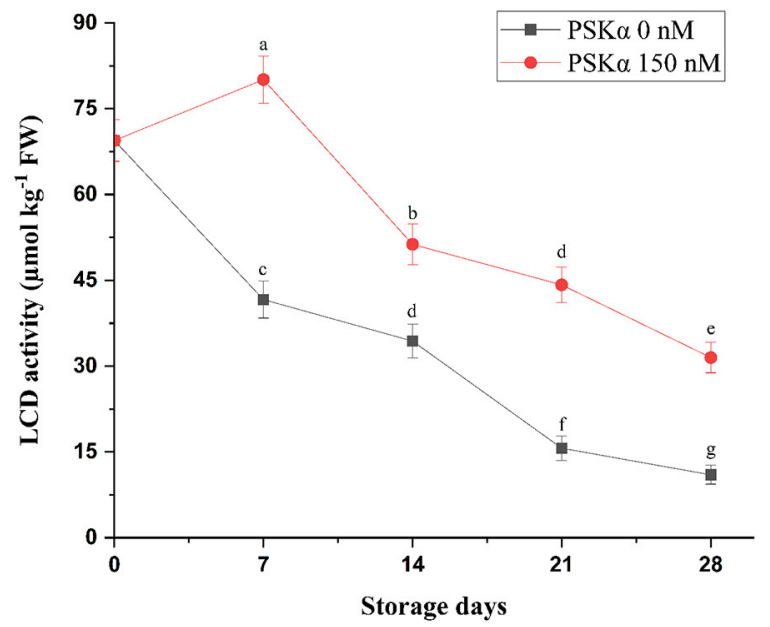

E

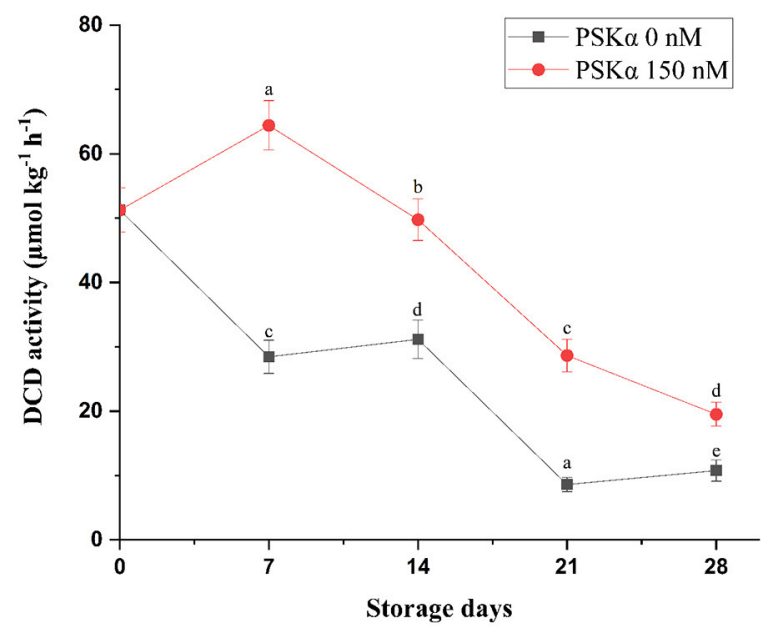

FIGURE 3 | Endogenous $\mathrm{H}_{2} \mathrm{~S}$ accumulation (A) accompanied by $L C D$ and $D C D$ gene expressions (B,C) and enzyme activities (D,E) in broccoli floret treated with PSK $\alpha$ at 0 and $150 \mathrm{nM}$ during storage at $4^{\circ} \mathrm{C}$ for 28 days. Data shown are mean values of $n=3$, and the error bars represent standard errors of the means. Tukey's test at $P=0.05$ level. 
$\mathrm{SDH}$, and $\mathrm{CCO}$ enzyme activities accompanied by higher SOD, CAT, and APX enzyme activities leading to lower $\mathrm{O}_{2}^{-}$and $\mathrm{H}_{2} \mathrm{O}_{2}$ accumulation, keeping membrane integrity signifying lower MDA accumulation. Aghdam et al. (27) reported that relieving chilling damage in hawthorn fruit treated with $\mathrm{H}_{2} \mathrm{~S}$ might be ascribed to endogenous $\mathrm{H}_{2} \mathrm{~S}$ accumulation resulting from higher LCD and DCD enzyme activities efficient for higher SOD, CAT, and APX enzyme activities leading to lower $\mathrm{H}_{2} \mathrm{O}_{2}$ accumulation; higher phenols, flavonoids, and anthocyanins accumulation; and higher DPPH scavenging activity resulting from higher PAL enzyme activity, keeping membrane integrity signifying lower MDA accumulation. Therefore, higher endogenous $\mathrm{H}_{2} \mathrm{~S}$ accumulation in broccoli floret treated with PSK $\alpha$ at $150 \mathrm{nM}$ might be attributed to higher $L C D$ and $D C D$ gene expressions and enzyme activities during storage at $4^{\circ} \mathrm{C}$ for 28 days efficient for suppressing floret yellowing by suppressing ethylene biosynthesis and chlorophyll degradation.

Endogenous $\mathrm{H}_{2} \mathrm{~S}$ accumulation serves as a signaling molecule by persulfidation, a protein post-translational modification (PTM). By exogenous $\mathrm{H}_{2} \mathrm{~S}$ application or endogenous $\mathrm{H}_{2} \mathrm{~S}$ accumulation, NADPH oxidase, LCD, APX, and glyceraldehyde 3-phosphate dehydrogenase (GAPDH) activity upregulation and ACO, NADP-isocitrate dehydrogenase (NADP-ICDH), NADPmalic enzyme (NADP-ME), and CAT activity downregulation have been attributed to persulfidation (52). González-Gordo et al. (53) suggested that the endogenous $\mathrm{H}_{2} \mathrm{~S}$ accumulation regulates the metabolism of plant organelles cytosol, chloroplast, mitochondrion, and peroxisome by persulfidation. Jia et al. (28) reported that the endogenous accumulation of $\mathrm{H}_{2} \mathrm{~S}$ suppresses ethylene biosynthesis by inhibiting the activity of ACO following cysteine persulfidation. Recently, Li et al. (54) reported that the $\mathrm{H}_{2} \mathrm{~S}$ conferred oxidative stress tolerance to tomato plants by persulfidation of ROS scavenging CAT and APX. Therefore, possibly, the endogenous accumulation of $\mathrm{H}_{2} \mathrm{~S}$ suppresses ethylene biosynthesis, due to lower activities of ACS and $\mathrm{ACO}$ and a suppressed chlorophyll degradation due to lower activities of MDC and $\mathrm{PPH}$ by protein persulfidation. However, this assumption needs to be validated in future studies by employing other methods, such as an improved tag-switch method for the in situ labeling of intracellular persulfides (55).

\section{REFERENCES}

1. Duarte-Sierra A, Nadeau F, Angers P, Michaud D, Arul J. UVC hormesis in broccoli florets: preservation, phyto-compounds and gene expression. Postharvest Biol Technol. (2019) 157:110965. doi: 10.1016/j.postharvbio.2019.110965

2. Shi J, Gao L, Zuo J, Wang Q, Wang Q, Fan L. Exogenous sodium nitroprusside treatment of broccoli florets extends shelf life, enhances antioxidant enzyme activity, and inhibits chlorophyll-degradation. Postharvest Biol Technol. (2016) 116:98-104. doi: 10.1016/j.postharvbio.2016.01.007

3. Silva-Sanzana C, Balic I, Sepúlveda P, Olmedo P, León G, Defilippi BG, et al. Effect of modified atmosphere packaging (MAP) on rachis quality of 'Red Globe' table grape variety. Postharvest Biol Technol. (2016) 119:33-40. doi: 10.1016/j.postharvbio.2016.04.021

\section{CONCLUSION}

To sum up, our results demonstrated that the exogenous PSK $\alpha$ application at $150 \mathrm{nM}$ may be employed as a promising procedure for delaying senescence of broccoli floret by promoting endogenous $\mathrm{H}_{2} \mathrm{~S}$ accumulation resulting from higher $L C D$ and $D C D$ gene expressions and enzyme activities giving to suppressing ethylene production resulting from lower ACS1 and ACO1 gene expressions and enzyme activities accompanied by higher chlorophyll accumulation resulting from lower $\mathrm{PPH}$ and $\mathrm{PaO}$ gene expressions concomitant with lower MDC and $\mathrm{PPH}$ enzyme activities during storage at $4^{\circ} \mathrm{C}$ for 28 days. The present study demonstrated the efficiency of $150 \mathrm{nM}$ PSK $\alpha$ treatment as a preservation procedure for postharvest broccoli to delay floret yellowing, and thus the use of $150 \mathrm{nM}$ PSK $\alpha$ may have broad application prospects. Thus, exogenous PSK $\alpha$ application can be employed as a beneficial strategy for delaying the senescence of broccoli floret during low temperature storage.

\section{DATA AVAILABILITY STATEMENT}

The raw data supporting the conclusions of this article will be made available by the authors, without undue reservation.

\section{AUTHOR CONTRIBUTIONS}

MSA conceived the idea and wrote the manuscript. MSA, $\mathrm{MA}-\mathrm{K}$, and RK performed the experiments and supported the data analysis. All the authors read, discussed, and approved the manuscript.

\section{ACKNOWLEDGMENTS}

The authors are grateful to Imam Khomeini International University (IKIU) for providing financial support.

\section{SUPPLEMENTARY MATERIAL}

The Supplementary Material for this article can be found online at: https://www.frontiersin.org/articles/10.3389/fnut.2021. 609217/full\#supplementary-material

4. Li D, Li L, Ge Z, Limwachiranon J, Ban Z, Yang D, et al. Effects of hydrogen sulfide on yellowing and energy metabolism in broccoli. Postharvest Biol Technol. (2017) 129:136-42. doi: 10.1016/j.postharvbio.2017.03.017

5. Liu M-S, Li H-C, Lai Y-M, Lo H-F, Chen L-FO. Proteomics and transcriptomics of broccoli subjected to exogenously supplied and transgenic senescence-induced cytokinin for amelioration of postharvest yellowing. $J$ Proteomics. (2013) 93:133-44. doi: 10.1016/j.jprot.2013.05.014

6. Cai J-H, Luo F, Zhao Y-B, Zhou Q, Wei B-D, Zhou X, et al. 24-Epibrassinolide treatment regulates broccoli yellowing during shelf life. Postharvest Biol Technol. (2019) 154:87-95. doi: 10.1016/j.postharvbio.2019.04.019

7. Aiamla-Or S, Shigyo M, Yamauchi N. UV-B treatment controls chlorophyll degradation and related gene expression in broccoli (Brassica oleracea L. Italica Group) florets during storage. Sci Hortic. (2019) 243:524-7. doi: 10.1016/j.scienta.2018.09.009 
8. Zheng Q, Zuo J, Gu S, Gao L, Hu W, Wang Q, et al. Putrescine treatment reduces yellowing during senescence of broccoli (Brassica oleracea L. var italica) Postharvest Biol Technol. (2019) 152:29-35. doi: 10.1016/j.postharvbio.2019.02.014

9. Yan Z, Shi J, Gao L, Wang Q, Zuo J. The combined treatment of broccoli florets with kojic acid and calcium chloride maintains post-harvest quality and inhibits off-odor production. Sci Hortic. (2020) 262:109019. doi: 10.1016/j.scienta.2019.109019

10. Xu F, Wang $\mathrm{H}$, Tang $\mathrm{Y}$, Dong $\mathrm{S}$, Qiao $\mathrm{X}$, Chen $\mathrm{X}$, et al. Effect of 1-methylcyclopropene on senescence and sugar metabolism in harvested broccoli florets. Postharvest Biol Technol. (2016) 116:45-9. doi: 10.1016/j.postharvbio.2016.01.004

11. Li S-P, Hu K-D, Hu L-Y, Li Y-H, Jiang A-M, Xiao F, et al. Hydrogen sulfide alleviates postharvest senescence of broccoli by modulating antioxidant defense and senescence-related gene expression. J Agric Food Chem. (2014) 62:1119-29. doi: 10.1021/jf4047122

12. Reyes Jara AM, Gómez-Lobato ME, Civello PM, Martínez GA. Effects of hormonal and physical treatments on the expression of a putative chlorophyll b reductase gene (BoNYC1) during postharvest senescence of broccoli. Postharvest Biol Technol. (2019) 147:107-12. doi: 10.1016/j.postharvbio.2018.09.010

13. Xu D, Zuo J, Fang Y, Yan Z, Shi J, Gao L, et al. Effect of folic acid on the postharvest physiology of broccoli during storage. Food Chem. (2021) 339:127981. doi: 10.1016/j.foodchem.2020.127981

14. Wu C, Cao S, Xie K, Chi Z, Wang J, Wang H, et al. Melatonin delays yellowing of broccoli during storage by regulating chlorophyll catabolism and maintaining chloroplast ultrastructure. Postharvest Biol Technol. (2021) 172:111378. doi: 10.1016/j.postharvbio.2020.111378

15. Sohail M, Wills RBH, Bowyer MC, Pristijono P. Beneficial impact of exogenous arginine, cysteine and methionine on postharvest senescence of broccoli. Food Chem. (2021) 338:128055. doi: 10.1016/j.foodchem.2020.128055

16. Aghdam MS, Sayyari M, Luo Z. Exogenous application of phytosulfokine $\alpha$ (PSK $\alpha$ ) delays yellowing and preserves nutritional quality of broccoli florets during cold storage. Food Chemistry. (2020) 333:127481. doi: 10.1016/j.foodchem.2020.127481

17. Aghdam MS, Flores FB. Employing phytosulfokine $\alpha(\mathrm{PSK} \alpha)$ for delaying broccoli florets yellowing during cold storage. Food Chem. (2021) 129626. doi: 10.1016/j.foodchem.2021.129626

18. Aghdam MS, Luo Z. Exogenous application of phytosulfokine $\alpha$ (PSK $\alpha$ ) delays senescence in broccoli florets during cold storage by ensuring intracellular ATP availability and avoiding intracellular ROS accumulation. Sci Hortic. (2021) 276:109745. doi: 10.1016/j.scienta.2020.109745

19. Huo J, Huang D, Zhang J, Fang H, Wang B, Wang C, et al. Hydrogen sulfide: a gaseous molecule in postharvest freshness. Front Plant Sci. (2018) 9:1172. doi: 10.3389/fpls.2018.01172

20. Ziogas V, Molassiotis A, Fotopoulos V, Tanou G. Hydrogen sulfide: a potent tool in postharvest fruit biology and possible mechanism of action. Front Plant Sci. (2018) 9:1375. doi: 10.3389/fpls.2018.01375

21. Ali S, Nawaz A, Ejaz S, Haider ST-A, Alam MW, Javed HU. Effects of hydrogen sulfide on postharvest physiology of fruits and vegetables: an overview. Sci Hortic. (2019) 243:290-9. doi: 10.1016/j.scienta.2018.08.037

22. Hu H, Liu D, Li P, Shen W. Hydrogen sulfide delays leaf yellowing of stored water spinach (Ipomoea aquatica) during dark-induced senescence by delaying chlorophyll breakdown, maintaining energy status and increasing antioxidative capacity. Postharvest Biol Technol. (2015) 108:8-20. doi: 10.1016/j.postharvbio.2015.05.003

23. Luo Z, Li D, Du R, Mou W. Hydrogen sulfide alleviates chilling injury of banana fruit by enhanced antioxidant system and proline content. Sci Hortic. (2015) 183:144-51. doi: 10.1016/j.scienta.2014.12.021

24. $\mathrm{Li} \mathrm{D}$, Limwachiranon $\mathrm{J}$, $\mathrm{Li} \mathrm{L}, \mathrm{Du} \mathrm{R}$, Luo $\mathrm{Z}$. Involvement of energy metabolism to chilling tolerance induced by hydrogen sulfide in cold-stored banana fruit. Food Chem. (2016) 208:272-8. doi: 10.1016/j.foodchem.2016. 03.113

25. Módis K, Ju Y, Ahmad A, Untereiner AA, Altaany Z, Wu L, et al. S-Sulfhydration of ATP synthase by hydrogen sulfide stimulates mitochondrial bioenergetics. Pharmacol Res. (2016) 113:116-24. doi: $10.1016 /$ j.phrs.2016.08.023
26. Liu D, Xu S, Hu H, Pan J, Li P, Shen W. Endogenous hydrogen sulfide homeostasis is responsible for the alleviation of senescence of postharvest daylily flower via increasing antioxidant capacity and maintained energy status. J Agric Food Chem. (2017) 65:718-26. doi: 10.1021/acs.jafc.6b04389

27. Aghdam MS, Mahmoudi R, Razavi F, Rabiei V, Soleimani A. Hydrogen sulfide treatment confers chilling tolerance in hawthorn fruit during cold storage by triggering endogenous $\mathrm{H} 2 \mathrm{~S}$ accumulation, enhancing antioxidant enzymes activity and promoting phenols accumulation. Sci Hortic. (2018) 238:264-71. doi: 10.1016/j.scienta.2018.04.063

28. Jia H, Chen S, Liu D, Liesche J, Shi C, Wang J, et al. Ethylene-induced hydrogen sulfide negatively regulates ethylene biosynthesis by persulfidation of ACO in tomato under osmotic stress. Front Plant Sci. (2018) 9:1517. doi: 10.3389/fpls.2018.01517

29. Jin Z, Sun L, Yang G, Pei Y. Hydrogen sulfide regulates energy production to delay leaf senescence induced by drought stress in arabidopsis. Front Plant Sci. (2018) 9:1722. doi: 10.3389/fpls.2018.01722

30. Munoz-Vargas M A, Gonzalez-Gordo S, Canas A, Lopez-Jaramillo J, Palma JM, Corpas FJ. Endogenous hydrogen sulfide (H2S) is up-regulated during sweet pepper (Capsicum annuum L.) fruit ripening. In vitro analysis shows that NADP-dependent isocitrate dehydrogenase (ICDH) activity is inhibited by H2S and NO. Nitric Oxide. (2018) 81:36-45. doi: 10.1016/j.niox.2018.10.002

31. Sauter M. Phytosulfokine peptide signalling. J Exp Bot. (2015) 66:5161-9. doi: 10.1093/jxb/erv071

32. Kaufmann C, Sauter M. Sulfated plant peptide hormones. J Exp Bot. (2019) 70:4267-77. doi: 10.1093/jxb/erz292

33. Song $\mathrm{H}$, Wang $\mathrm{X}, \mathrm{Hu} \mathrm{W}$, Yang $\mathrm{X}$, Diao E, Shen $\mathrm{T}$, et al. A coldinduced phytosulfokine peptide is related to the improvement of loquat fruit chilling tolerance. Food Chem. (2017) 232:434-42. doi: 10.1016/j.foodchem.2017.04.045

34. Zhang $\mathrm{H}$, $\mathrm{Hu} \mathrm{Z}$, Lei $\mathrm{C}$, Zheng $\mathrm{C}$, Wang J, Shao S, et al. A plant phytosulfokine peptide initiates auxin-dependent immunity through cytosolic Ca2+ signaling in tomato. The Plant Cell. (2018) 30:652-67. doi: 10.1105/tpc.17.00537

35. Aghdam MS, Alikhani-Koupaei M. Exogenous phytosulfokine $\alpha(\mathrm{PSK} \alpha)$ applying delays senescence and relief decay in strawberry fruits during cold storage by sufficient intracellular ATP and NADPH availability. Food Chem. (2021) 336:127685. doi: 10.1016/j.foodchem.2020.127685

36. Aghdam MS, Flores FB, Sedaghati B. Exogenous phytosulfokine $\alpha$ $(\mathrm{PSK} \alpha)$ application delays senescence and relieves decay in strawberry fruit during cold storage by triggering extracellular ATP signaling and improving ROS scavenging system activity. Sci Hortic. (2021) 279:109906. doi: 10.1016/j.scienta.2021.109906

37. Aghdam MS, Sayyari M, Luo Z. Exogenous phytosulfokine $\alpha$ application delays senescence and promotes antioxidant nutrient accumulation in strawberry fruit during cold storage by triggering endogenous phytosulfokine $\alpha$ signaling. Postharvest Biol Technol. (2021) 175:111473. doi: $10.1016 /$ j.postharvbio.2021.111473

38. Gomez-Lobato ME, Civello PM, Martínez GA. Expression of a lipoxygenase encoding gene (BoLOX1) during postharvest senescence of broccoli. Postharvest Biol Technol. (2012) 64:146-53. doi: 10.1016/j.postharvbio.2011.07.003

39. Fan L, Shi J, Zuo J, Gao L, Lv J, Wang Q. Methyl jasmonate delays postharvest ripening and senescence in the non-climacteric eggplant (Solanum melongena L.) fruit. Postharvest Biol Technol. (2016) 120:76-83. doi: 10.1016/j.postharvbio.2016.05.010

40. Suzuki Y, Asoda T, Matsumoto Y, Terai H, Kato M. Suppression of the expression of genes encoding ethylene biosynthetic enzymes in harvested broccoli with high temperature treatment. Postharvest Biol Technol. (2005) 36:265-71. doi: 10.1016/j.postharvbio.2005.02.005

41. Suzuki Y, Uji T, Terai H. Inhibition of senescence in broccoli florets with ethanol vapor from alcohol powder. Postharvest Biol Technol. (2004) 31:17782. doi: $10.1016 /$ j.postharvbio.2003.08.002

42. Livak KJ, Schmittgen TD. Analysis of relative gene expression data using realtime quantitative PCR and the 2- $\Delta \Delta$ CT method. Methods. (2001) 25:402-8. doi: 10.1006/meth.2001.1262

43. Hunter DA, Pinkney TT, Watson LM, Trivellini A, Janssen BJ, Brummell DA, et al. Effect of postharvest water deficit stress on gene expression in heads 
of broccoli (Brassica oleracea var. italica) Postharvest Biol Technol. (2011) 59:113-23. doi: 10.1016/j.postharvbio.2010.09.010

44. Fang H, Luo F, Li P, Zhou Q, Zhou X, Wei B, et al. Potential of jasmonic acid (JA) in accelerating postharvest yellowing of broccoli by promoting its chlorophyll degradation. Food Chem. (2020) 309:125737. doi: 10.1016/j.foodchem.2019.125737

45. Gómez-Lobato ME, Hasperué JH, Civello PM, Chaves AR, Martínez GA. Effect of 1-MCP on the expression of chlorophyll degrading genes during senescence of broccoli (Brassica oleracea L.). Sci Hortic. (2012) 144:208-11. doi: 10.1016/j.scienta.2012.07.017

46. Gómez-Lobato ME, Mansilla SA, Civello PM, Martínez GA. Expression of Stay-Green encoding gene (BoSGR) during postharvest senescence of broccoli. Postharvest Biol Technol. (2014) 95:88-94. doi: 10.1016/j.postharvbio.2014.04.010

47. Chen LFO, Lin CH, Kelkar SM, ChangYM, ShawJF. Transgenic broccoli (Brassica oleracea var. italica) with antisense chlorophyllase (BoCLH1) delays postharvest yellowing. Plant Sci. (2008) 174:25-31. doi: 10.1016/j.plantsci.2007.09.006

48. Hortensteiner S, Krautler B. Chlorophyll breakdown in higher plants. Biochim Biophys Acta. (2011) 1807:977-88. doi: 10.1016/j.bbabio.2010.12.007

49. Aiamla-Or S, Kaewsuksaeng S, Shigyo M, Yamauchi N. Impact of UV-B irradiation on chlorophyll degradation and chlorophyll-degrading enzyme activities in stored broccoli (Brassica oleracea L. Italica Group) florets. Food Chem. (2010) 120:645-51. doi: 10.1016/j.foodchem.2009.10.056

50. Buchert AM, Civello PM, Martinez GA. Chlorophyllase versus pheophytinase as candidates for chlorophyll dephytilation during senescence of broccoli. $J$ Plant Physiol. (2011) 168:337-43. doi: 10.1016/j.jplph.2010.07.011

51. Aiamla-Or S, Nakajima T, Shigyo M, Yamauchi N. Pheophytinase activity and gene expression of chlorophyll-degrading enzymes relating to UV-B treatment in postharvest broccoli (Brassica oleracea L. Italica Group) florets. Postharvest Biol Technol. (2012) 63:60-6. doi: 10.1016/j.postharvbio.2011. 08.003

52. Corpas FJ, Palma JM. H2S signaling in plants and applications in agriculture. J Adv Res. (2020) 24:131-7. doi: 10.1016/j.jare.2020.03.011

53. González-Gordo S, Palma JM, Corpas FJ. Appraisal of H2S metabolism in Arabidopsis thaliana: In silico analysis at the subcellular level. Plant Physiol Biochem. (2020) 155:579-88. doi: 10.1016/j.plaphy.2020. 08.014

54. Li J, Shi C, Wang X, Liu C, Ding X, Ma P, et al. Hydrogen sulfide regulates the activity of antioxidant enzymes through persulfidation and improves the resistance of tomato seedling to copper oxide nanoparticles ( $\mathrm{CuO}$ NPs)-induced oxidative stress. Plant Physiol Biochemi. (2020) 156:257-66. doi: 10.1016/j.plaphy.2020.09.020

55. Kouroussis E, Adhikari B, Zivanovic J, Filipovic, MR. Measurement of protein persulfidation: improved tag-switch method. Vasc Eff Hydrogen Sulfide. (2019) 2007:37-50. doi: 10.1007/978-1-4939-9528-8_4

Conflict of Interest: The authors declare that the research was conducted in the absence of any commercial or financial relationships that could be construed as a potential conflict of interest.

Copyright (c) 2021 Aghdam, Alikhani-Koupaei and Khademian. This is an openaccess article distributed under the terms of the Creative Commons Attribution License (CC BY). The use, distribution or reproduction in other forums is permitted, provided the original author(s) and the copyright owner(s) are credited and that the original publication in this journal is cited, in accordance with accepted academic practice. No use, distribution or reproduction is permitted which does not comply with these terms. 